\title{
IMPROVING STUDENTS' WRITING RECOUNT TEXT ACHIEVEMENT THROUGH MIND MAPPING TECHNIQUE IN JUNIOR HIGH SCHOOL
}

\author{
* Maria Rosa Marpaung \\ **Johan Sinulingga
}

\begin{abstract}
This study concerns with improvement of students' achievement in writing recount text through mind mapping technique in Junior High School. The subject of the study was the students in SMP Free Methodist 1 Medan, class VIII-1 which consisted of 37 students. This study was conducted by applying Classroom Action Research. The procedure of this research was done in two cycles in six meeting. The mean of students' score in test I was 67.24. It was increased in test II to 72.78 and in test III, it became 78.79. The improvement was not only showed in the mean of the students' score but also in the number of students who got point up to 75 . In test I, the number of students who got point up to 75 was only $5.4 \%$. In test II, the number was increased to $29.8 \%$ while in test III it became $81.1 \%$. Based on the diary notes, observation sheet and questionnaire sheet, it was found that the students gave good responds in the teaching and learning process. Based on the result of quantitative and qualitative data, it can be concluded that the application of mind mapping technique had improved the junior high school students' achievement in writing recount text.
\end{abstract}

Keywords: Writing, Recount Text, Mind Mapping, Junior High School

\footnotetext{
* A graduate of English Language and Literature Department of UNIMED

** A lecturer of English Language and Literature Department of UNIMED
} 


\section{INTRODUCTION}

\section{The Background of the Study}

English, as an international language, has been used by people all over the world as the main instrument of communication. English becomes more important in life since it is parallel to the development of science and technology. In Indonesia, English has been taught from the Kindergarten up to University level. But in fact, there are still many people who cannot comprehend English well.

Writing is one of language skills in learning English. Tiwari (2005 : 120) states that writing is a complex process that allows the writer to explore thoughts and ideas and make them visible and concrete. Writing is a process of transforming thoughts and ideas into written from. According to Nunan (2003 :88) writing is a mental work of inventing ideas, thinking about how to express them into statements and paragraphs that will be cleared to the reader.

Actually, writing is a good way to develop English ability, but most of the students still say that it is difficult to express their idea in writing. Oshima and Hogue (1991 : 5) state that writing always has problems which put students into trouble as shown by errors made in both the organizing of the composition and the language so that the students' writing topic cannot be stated correctly. It is believed that developing writing skills is more complicated than developing other language skills. In order to be able to write well, the students need to be equipped with early and continued writing experiences. Thus, the teacher's task to develop the students' writing skill is more complicated than the other skills.

Based on the observation result on the teaching and learning activity in SMP Free Methodist 1 Medan, it was revealed that the teaching and learning activity in the class put no attention to the prewriting stage so the students' achievement was low. Most of the students stated that their problem in writing is that they do not have many ideas to write. Moreover, the teacher usually gives a little theory to them and told them to write an essay about the topic without guiding them to think creatively and to associate ideas easily. Because of this problem, most of the students are not able to write well. 
From the reason that is stated above, the way of teaching needs to be improved. The appropriate method, technique, or strategy can solve the difficulties of student in writing. Langan (2003 : 12) states that writing is a skill, so it can be learnt by using many kinds of technique. To solve the students' problem in writing, the writer tries to improve the students' achievement in writing recount text through mind mapping technique. Here, the students are expected to be able to find out the related words, ideas and concepts as many as possible to the topic given. According to Buzan (2004), mind mapping is an effective technique that can be used to help teacher because it is not difficult to be applied. It also creates enjoyable classroom atmosphere in the teaching and learning process.

Mind mapping works well as the teacher's visual design that enables students to see the relationship between the ideas, and encourages them to group certain ideas together as they proceed. Students start with a topic at the center and then generate a web of ideas from it, developing and relating these ideas make associations. Mind mapping is often created around a single word or text, placed in the center, to which associated ideas, words and concepts are added.

A research about Mind mapping as a technique had also been conducted by Rafika Raisa Siregar (2010). She conducted this technique to improve the students' problem in writing recount paragraph in senior high school grade $\mathrm{X}$. She focused on the students' grammar and vocabulary improvement while writing recount paragraph. Here, in this research, the writer focused on the junior high school students' problem in writing recount text since they don't have many ideas to write. So, the writer's expectation after applying mind mapping technique is that the students become more creative to write. They always can find new ideas while writing recount text.

\section{Research Question}

Based on the background of study, the problem of study will be formulated as follows : "Is the Junior High School students' achievement in writing recount text improved if they are taught by using mind mapping technique?" 


\section{METHODOLOGY}

\section{Research Design}

This study applied Classroom Action Research (CAR). Classroom Action Research aims to improve the quality of English teacher's performance in teaching. It gives the educator new opportunities to reflect on and asses their teaching; to explore and test new ideas, methods, and materials; or to assess how effective the new approaches were. In other words, Classroom Action Research is a strategy done by teachers to improve the quality of teacher's performance in teaching-learning process for better students' English achievements.

Action research is an observation of an activity that is appears consciously in a collecting data on everyday practice then analyzing in order to make some decision about future practice should be. According to Tomal (2003:20) action research is a systematic process of solving educational problems and making improvements. An action researcher utilizes an appropriate intervention to collect and analyze data and to implement actions to address educational issues. Further, Tomal (2010:14) states that in action research, the researcher is concerned with using a systematic process in solving educational problems and making improvements. Action research is suitable for educators as a practical process because it generally does not require elaborate statistical analysis.

Based on the explanation above, action research was qualified to be used in order to see the improvement of students' recount writing through mind mapping technique. It was expected by using action research : the improvement of students' recount writing text will be achieved. 


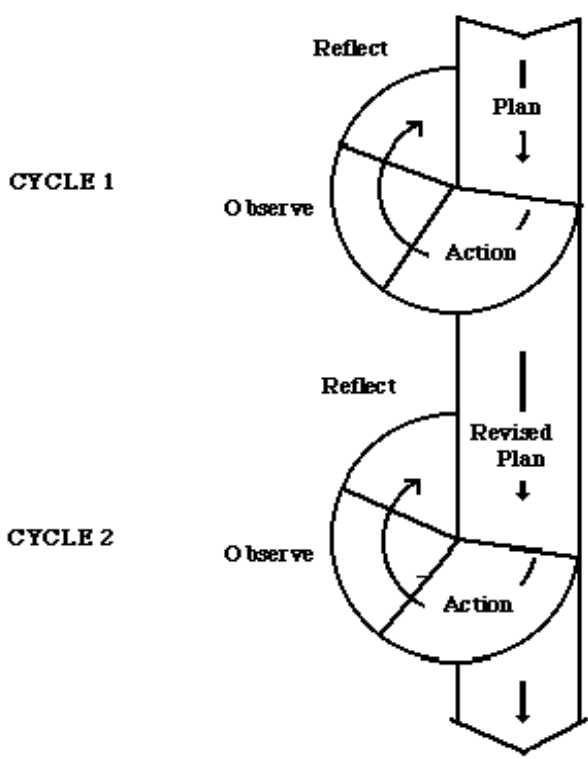

The Action Research Spiral (based on Kemmis \& McTaggart 1988:14)

The subject of this research was the second year students of SMP Free Methodist 1 Medan which consisted of 37 students

The data were collected by using quantitative and qualitative data. Quantitative data were collected by computing students' writing score. In collecting the quantitative data, the writer conducted written test. The students were asked to write a Recount paragraph through mind mapping technique.

In collecting qualitative data; observation sheet, questionnaire sheet and diary notes were used. Observation sheet was used to identify all condition that happened during the teaching and learning process. Questionnaire sheet was used to know feeling, problem and other condition of the students. Diary note was used to analyze in order to know all things that contained the writer personal evaluation about the running class.

The procedures of data collecting were performed by administrating for six meeting for two cycles. The first cycle consists of three meetings and the second cycle consists of three meetings. Each cycle contained for steps, they are : 1) Planning, 2) Action, 3) Observation, and 4) Reflecting.

Qualitative and Quantitative were used in this study. By applying these data, it was expected to get the satisfying result. The qualitative data were analyzed from the observation sheet, questionnaire sheet, and diary notes to describe the improvement of students' recount writing through mind mapping technique. The quantitative data were collected by analyzed by computing the score of writing test. To collect data, the writer 
observed these activities through mind mapping technique that was given to the students as their concern to write the achievement of the students.

To know the mean of the students' score in each cycle, the following formulas were applied :

$$
x=\frac{\sum X}{N}
$$

where, $\quad \mathrm{x} \quad=$ The mean of students' score

$$
\sum X \quad=\text { The total score }
$$

$\mathrm{N} \quad=$ The number of the students

Next, to categorize the number of students who were competent in writing Recount text, the following formula was applied :

$$
P=\frac{R}{T} \times 100 \%
$$

$$
\text { where, } \quad \begin{array}{ll}
\mathrm{P} & =\text { The percentage of those who get the points up to } 75 \\
\mathrm{R} & =\text { The number of students who get the points up to } 75 \\
\mathrm{~T} & =\text { The total number of students }
\end{array}
$$

\section{RESULTS AND DISCUSSION}

\section{The Data}

This study was applied by using quantitative and qualitative data. The quantitative data was taken from writing test scores and the qualitative data was taken from the questionnaire sheet, observation sheet and diary notes. The data were collected from class VIII-1 which was consisted of 37 students.

This research was accomplished in two cycles. Each cycle consisted of four steps of action research (planning, action, observation, and reflection). The first cycle was conducted in three meeting and the second cycle was also conducted in three meeting. So, there were six meeting altogether.

\section{The quantitative data}

The qualitative data were taken from the score of writing tests administered in three times; test I (in the first meeting), test II (in cycle 1) and test III (in cycle 2). 
The score of the students showed improvement continuously. The improvement of the students' score in writing recount text through mind mapping technique can be seen in table 4.1 (page 28) and the calculation can be seen in Appendix B.

\section{The qualitative data}

The qualitative data were collected from the observation sheet, questionnaire sheet, and diary notes. The observation sheet was used to measure the level of students' activities during teaching-learning process in which mind mapping technique was applied, students' activities and behavior, students' achievement in writing recount text, and the interaction between teacher and students. The observation sheet indicated that most students were active during teaching learning process through mind mapping technique. The observation sheet can be seen in appendix E (page 68).

The questionnaire sheet was used to know the students opinion, perception, and respond about the topic given. It showed that the students could expand their ideas in writing after mind mapping technique was applied. It shows that mind mapping technique helped the students to be able to state their idea in writing recount text. The questionnaire sheet can be seen in appendix D.

Last, diary notes were analyzed in order to know all things that contained the research personal evaluation in every meeting during conducting the research. The diary notes indicated that the students were interested in learning recount text through mind mapping technique. The diary notes can be seen in appendix $\mathrm{C}$.

\section{The Data Analysis}

\section{Analysis of quantitative data}

The students' score increased from the first competence test to the last competence test. It can be seen in the table below.

Students Writing Scores in Test I, Test II, and Test III

\begin{tabular}{|c|c|c|c|c|}
\hline No & Students' Initial Name & Test I & Test II & Test III \\
\hline 1 & ALS & 63 & 67 & 71 \\
\hline 2 & ACD & 65 & 70 & 75 \\
\hline 3 & ARP & 68 & 71 & 75 \\
\hline 4 & BAS & 70 & 74 & 85 \\
\hline 5 & DRM & 66 & 76 & 88 \\
\hline
\end{tabular}




\begin{tabular}{|c|c|c|c|c|}
\hline 6 & DAW & 65 & 70 & 74 \\
\hline 7 & EMS & 69 & 75 & 80 \\
\hline 8 & ETA & 72 & 79 & 89 \\
\hline 9 & GMH & 65 & 70 & 72 \\
\hline 10 & HSS & 71 & 77 & 82 \\
\hline 11 & INM & 70 & 75 & 87 \\
\hline 12 & JUS & 66 & 76 & 87 \\
\hline 13 & JHP & 69 & 75 & 82 \\
\hline 14 & JAH & 69 & 74 & 80 \\
\hline 15 & KPS & 64 & 70 & 76 \\
\hline 16 & KAP & 65 & 76 & 85 \\
\hline 17 & KG & 67 & 74 & 80 \\
\hline 18 & LAS & 70 & 73 & 75 \\
\hline 19 & MRS & 65 & 68 & 74 \\
\hline 20 & MS & 68 & 74 & 78 \\
\hline 21 & OJT & 66 & 70 & 73 \\
\hline 22 & PFG & 62 & 69 & 76 \\
\hline 23 & PCP & 68 & 74 & 78 \\
\hline 24 & RMS & 60 & 68 & 75 \\
\hline 25 & RHT & 67 & 71 & 76 \\
\hline 26 & RFP & 66 & 70 & 73 \\
\hline 27 & SMS & 69 & 74 & 77 \\
\hline 28 & $\overline{S A}$ & 65 & 69 & 76 \\
\hline 29 & $\mathrm{SP}$ & 77 & 86 & 91 \\
\hline 30 & SAS & 75 & 79 & 84 \\
\hline 31 & TCS & 66 & 69 & 76 \\
\hline 32 & VBM & 65 & 71 & 77 \\
\hline 33 & VSH & 72 & 79 & 89 \\
\hline 34 & WS & 68 & 73 & 75 \\
\hline 35 & WEH & 64 & 68 & 76 \\
\hline 36 & YAM & 62 & 67 & 73 \\
\hline 37 & YHP & 69 & 72 & 75 \\
\hline \multirow{2}{*}{\multicolumn{2}{|c|}{ Total $\left(\sum x\right)$}} & 2488 & 2693 & 2915 \\
\hline & & & & \\
\hline \multirow{2}{*}{\multicolumn{2}{|c|}{ Mean $(X)$}} & 67.24 & 72.78 & 78.79 \\
\hline & & & & \\
\hline
\end{tabular}

Based on the table, we can see that in the first meeting, the students score was still low. Then after mind mapping technique was applied in the classroom, their score were improved started from test II and got more improved at test III. 
The students' writing was scored by calculating the scoring of recount text based on the assessment of recount text (table 3.1). The range of score improvement can be seen in the following table :

Range of Score Improvement

\begin{tabular}{|c|c|c|c|}
\hline No. & $\begin{array}{c}\text { Range of } \\
\text { Improvement Score }\end{array}$ & Students' Initial Name & Total \\
\hline 1 & $21-30$ & DRM, JUS & 2 \\
\hline 2 & $11-20$ & BAS, EMS, ETA, HSS, INM, JHP, JAH, KPS, & 18 \\
& & KAP, KG, PFG, RMS, SA, SP, VBM, VSH, WEH, & \\
& & YAM & 17 \\
\hline 3 & $1-10$ & ALS, ACD, ARP, DAW, GMH, LAS, MRS, MS, \\
& & OJT, PCP, RHT, RFP, SMS, SAS, TCS, WS, YHP & 37 \\
\hline
\end{tabular}

The increasing score from test I to test II can be seen below :

a. Students who got the improving score about $21-30$ points ( 2 students) $: 5.4 \%$

Their score significantly improved from cycle I to cycle II. They were active students. They always paid attention when the teacher gave explanation. They always asked questions and practiced hard. It was successfully achieved because they were willing to practice and learn from the mistakes before.

b. Students who got improving score about $11-20$ points (18 students) : 48.6\%

They were serious enough during the teaching-learning process. But they are shy to ask question about unclear material. Although they did not get the highest improvement but their score kept improving.

c. Students who got the improving scores about 1-10 (17 students) : 46\%

Although they got the least improving score of others, it did not mean that they were good enough in writing. Most of them paid attention to teacher's explanation and they were active students too. Even though their scores were not the highest among all, but they also had improvement score.

There were some differences between the lowest and the highest score of students' writing score within each test. The differences showed that there was improvement of students' achievement in writing recount text. The comparison of students' scores in each test can be seen in the following table : 
The Comparison of Students' Writing Scores

\begin{tabular}{|c|c|c|c|}
\hline Types of Score & Test I & Test II & Test III \\
\hline Lowest Score & 62 & 67 & 71 \\
\hline Highest Score & 77 & 86 & 91 \\
\hline
\end{tabular}

From the data above, it can be seen that students' score kept improving. In test I, the lowest score was 62 and the highest score was 77 . In test II, the lowest score was 67 and the highest score was 86. In test III, the lowest score was 71 and the highest score was 91. Those score showed the improvement of students' achievement in writing recount text.

The Percentage of Students who Got Point up to 75

\begin{tabular}{|c|c|c|}
\hline Test & $\begin{array}{c}\text { Students who got score } \\
\text { up to } \mathbf{7 5}\end{array}$ & Percentage \\
\hline Test I & 2 & $5.4 \%$ \\
\hline Test II & 11 & $29.8 \%$ \\
\hline Test III & 30 & $81.1 \%$ \\
\hline
\end{tabular}

In test $\mathrm{I}$, there were only $5.4 \%$ ( 2 students $)$ who got point up to 75 . The percentage kept improving after the mind mapping technique was applied. In test II, there were $29.8 \%$ (11 students) got point up to 75 and in test III, there were $81.1 \%$ students who got point up to 75 . It can be concluded that mind mapping technique can improve the students' achievement in writing recount text.

\section{Analysis of qualitative data}

The qualitative data were taken from diary notes, observation sheet, and questionnaire sheet. Diary notes were analyzed in order to know all things that contained the research personal evaluation in every meeting during conducting the research. The diary notes indicated that the students were interested in learning recount text through mind mapping technique. It was found that the students still confused in writing recount text in the first meeting. They did not have much idea about what they should write. Then, they were introduced mind mapping technique. They began to think creatively. They became enthusiastic in writing recount text. They could find idea easily 
after they made their first mind map. They could develop their recount text easily. So, in the end of this research, they were able to produce a good recount text because their score kept improving in every test. The complete data can be seen in appendix C.

The observation sheet was used to measure the level of students' activities during teaching-learning process in which mind mapping technique was applied, students' activities and behavior, students' achievement in writing recount text, and the interaction between teacher and students. The observation sheet indicated that most students were active during teaching learning process through mind mapping technique. The observation sheets were filled by the English teacher as a collaborator of this research. Based on the observation sheet, it can be concluded that the teaching and learning process ran well. The situation was comfort and enjoyable. The students became more active in teaching and learning process. They delivered questions about the material given. The result of the observation sheet can be seen in appendix D.

The questionnaire sheet was used to know the students opinion, perception, and respond about mind mapping technique in writing recount text. It showed that the students could expand their ideas in writing after mind mapping technique was applied. It shows that mind mapping technique helped the students to be able to state their idea in writing recount text. The questionnaire sheet was made up based on scale. They were strongly agreed (score 3), agreed (score 2), and disagreed (score 1). There were 10 statements which the maximum score was 30 . The complete data can be seen in appendix.

\section{RESULTS AND DISCUSSION}

\section{Research Findings}

The qualitative data and quantitative data were organized in this research. The first cycle was begun with test I in the first meeting. From the result of the test, it found out that the students' score in writing recount text was still low. They could not achieve the minimum score that was up to 75 point. They did not have many ideas to write. They just did not know how to develop the title into a good recount text. They still confused to construct sentences into paragraph. Then, mind mapping technique was applied in the third meetings. In the end of cycle I, test II was conducted to know whether their scores were improved or not. Test II showed that the score was higher 
than test I score. After test II was conducted, the students were given more explanation about how to use mind mapping technique in recount text. Then, test III were conducted in the end of cycle II and it showed that the students' achievement in writing recount text through mind mapping technique improved. Most of the students were able to achieve the standard score. The improvement of students' score in writing recount text can be seen in the following table :

The Improvement of Students' Score in Writing Recount Text

\begin{tabular}{|c|l|c|c|c|}
\hline No & \multicolumn{1}{|c|}{ Competences } & Test I & Test II & Test III \\
\hline 1 & Score & 2488 & 2693 & 2915 \\
\hline 2 & Mean & 67.24 & 72.78 & 78.79 \\
\hline 3 & $\begin{array}{l}\text { Number of students' who } \\
\text { got point up to 75 }\end{array}$ & 2 & 11 & 30 \\
\hline 4 & $\begin{array}{l}\text { Percentage of student } \\
\text { who got point up to 75 }\end{array}$ & $5.4 \%$ & $29.8 \%$ & $81.1 \%$ \\
\hline
\end{tabular}

From the table above, the mean of students' score in test I was 67.24. It was increased in test II to 72.78 and in test III, it became 78.79 . The improvement was not only showed in the mean of the students' score but also in the number of students who got point up to 75 . In test I, the number of students who got point up to 75 was only $5.4 \%$ ( 2 students). In test II, the number was increased to $29.8 \%$ (11 students) while in test III it became $81.1 \%$ (30 students).

The writer also analyzed the data which was gathered from diary notes, observation sheet and questionnaire sheet. It was found that the students' score in writing recount text through mind mapping technique was improved. The diary notes and observation sheet showed that the students gave good responds in the teaching and learning process. Although in the first time they still confused, they could handle the problem and start to enjoy the teaching and learning process. They became more active and interested in doing their test.

The questionnaire showed that most of the students strongly agreed that the application of mind mapping technique had helped them in writing recount text. Based on the result of quantitative and qualitative data, it was found that the application of mind mapping technique had improved the junior high school students' achievement in writing recount text. 


\section{CONCLUSION AND SUGGESTIONS}

\section{Conclusion}

After analyzing the data, it was found out that the students' writing score in writing recount text improved from the first cycle to the second cycle. It means that there was an improvement on the students' achievement in writing recount text through mind mapping technique. It states that the scores improve from the first test to the last test continuously. Therefore, it can be concluded that mind mapping technique can improve the Junior High School students' achievement in writing recount text.

\section{Suggestions}

The result of this study showed that the use of mind mapping technique can improve the Junior High School students' achievement in writing recount text. In relation above, some points are suggested as follows :

1) For the English teacher, it is better to use mind mapping technique in teaching recount text because this technique helps them to think creatively. So it will be easier and enjoyable for them to create a good recount text.

2) For the next researchers, who are interested for further study related to this research, should explore the knowledge to enlarge their understanding about how to improve Junior High School students' achievement in writing recount text and compare other references.

3) For all readers, may this research will bring you into good understanding about how to improve the Junior High School students' achievement in writing recount text through mind mapping technique. 


\section{REFERENCES}

Buzan, Tony. 2004. Mind Mapping Untuk Meningkatkan Kreatifitas. Jakarta : PT Gramedia Pustaka Utama. . 2005. Buku Pintar Mind Map. Jakarta : PT Gramedia Pustaka Utama.

Knapp, Peter., and Megan Watknis. 2005. Genre, Text, and Grammar. Sydney : University of New South Wales.

Oshima, Alice., and Ann Hogue. 1991. Writing Academic English. NY : Longman.

Sudarwati, Th. M. 2007. Look Ahead an English Course 1. Jakarta : Erlangga.

Tiwari, Deepak. 2005. Encyclopedia of Modern Methods of Teaching 7. New Delhi : Cressent.

Tomal, Daniel. R. 2003. Action Research for Educators. USA : Scarecrow Press. 
. 2010. Action Research for Educators. $2^{\text {nd }}$ Ed. UK : Rowman and Littlefield Publishers.

Novarina, Niesia. 2011. Implementing Mind Mapping Strategy to Improve the Writing Ability in Recount Text of The Eight Graders of SMPN 9 Malang. Thesis, English Education Program, Faculty of Letter, State University of Malang.

Siregar. Raisa. 2010. Improving Students' Achievement in Writing Recount Paragraph Through Mind Mapping Strategy. Thesis, English Education Program, Faculty of Letter, State University of Malang.

http://www.teachingenglish.org.uk/Mind-Mapping-Basic-Rules/March 22, 2012/16:40:03 